https://doi.org/10.31713/m1120

\title{
ANALYSIS AND RESEARCH OF RESOURCE-SAVING TECHNOLOGIES FOR ANAEROBIC DIGESTION OF BIOMASS
}

\author{
Avksentieva A.P, Kuris Yu.V.
}

Zaporizhzhia National University, bachelor, $4^{\text {th }}$ year student in the Department of Thermal Power Engineering and Hydropower, Ukraine.

Zaporizhzhia National University d.t.s., prof., educator in the Department of Applied Ecology and Occupational Safety, Ukraine.

\begin{abstract}
.
Biogas is a methane-containing gas produced by anaerobic decomposition of an organic substrate. To date, biogas is a potential gaseous fuel - a source of electrical and thermal energy production, with the capabilities of which the whole world is not fully familiar.

As an alternative energy source, it has many advantages and is a solution to many economic and environmental problems in the world, which could be a definite important step in improving the position of the Energy System of the world.

In this article the construction of mathematical model of biothermal process of waste treatment is considered that gives the possibility to study in full the mechanism of this phenomenon, to determine and describe the relationship between the main parameters of the studied object with the aim of its automation, for example, to optimize technological processes in the microbiological industry.

The methods of pig manure processing, which has both energy potential and economic, economic and nature protection potential, are also investigated. Pig manure processing can be carried out in

The following directions: obtaining organic fertilizer; fuel; fodder. For this purpose different methods of manure processing can be used, which can be divided into physical, chemical and biological.

The article presents a detailed analysis of methods of pig manure processing, as well as positive aspects of using this method to obtain fuel, fertilizer and fodder from the energy and economic sphere.

\section{Introduction.}

The construction of mathematical models of any objects is associated with the formalization of their description and with the identification of essential features of the situation under consideration. The mathematical model, summarizing the quantitative relationships between process factors, allows us to analyze their role in interaction and determine the optimal conditions for conducting the process.
\end{abstract}


Mathematical models are divided into three types: search, portrait, and research.

Search models are used in conditions where the mechanism of the described phenomenon is insufficiently studied. In this case, observing the reaction of the system under study to external influences creates a hypothetical model of the phenomenon, which is then empirically tested under various conditions in order to clarify its individual parameters. The search model can accurately describe the relationship of the main parameters of a real phenomenon. The disadvantage of models of this type is their limitations, since they are valid only under conditions close to those under which empirical coefficients were determined. Search models are rational in determining the optimal parameters of a particular object in order to automate it, for example, to optimize processing procedures in the microbiological industry. There are known attempts to use search models to describe the main stages of biological wastewater treatment, but due to the shortcomings noted above, they are not widely used in practice.

Portrait models are used in cases where the object's mechanism is relatively fully studied, but difficult for direct observations. This situation occurs in biology when studying genetic processes that last for years, or when studying the development of plant and animal populations.

The research model is used to find out the potential capabilities of the object under study, i.e. ways to intensify processes. Such a model should be based on theoretical prerequisites, but may also contain specific empirical relationships to describe the stages of the process having minor importance.

\section{Formation of a mathematical model.}

The whole process of developing a mathematical model can be divided into several different stages related to the collection of necessary information, with the analysis of experimental data and the identification of patterns, as well as the actual construction of a model based on the identified patterns, interpretation of the results of its analysis and comparison of theoretical (model) data with experimental ones. At each stage, a well-defined set of problems is solved.

At the first stage, general factors of bio thermal decomposition (the influence of initial moisture content of manure, initial temperature and some other physical quantities on the rate of the process) are 
investigated. As a result of research, factual material is accumulated and conclusions are drawn, first of all, of a qualitative character about the nature of the process. At this stage, it is very important to conduct experiments, for example, to identify the nature of the dependence of the duration of the process on the initial humidity of manure, the growth of biomass temperature, the presence of organic substances, the influence of filler on the degree of decomposition of organic matter, to identify the dependence of changes in the process rate on various factors. A huge role at this stage is played by the development of methods for collecting experimental information. Based on the results of the conducted experiments, the main parameters for changing the process are established.

At the second stage, a statistical analysis of the accumulated material is carried out, which leads to the identification of existing patterns (for example, the dependence of the duration of the process on temperature, etc.). These regularities are laid down in the basis of prognostic algorithms, which allow predicting with a certain probability the realization of these or other phenomena.

At the third stage, based on the identified patterns and statistical analysis, a mathematical model is formed that reflects these patterns in the form of mathematical expressions, dependencies, and formulas. Note that, as a rule, mathematical models do not rely on all available factual material, but only reflect the features of the object being modeled in a very simplified form.

Analysis of the literature on this issue allowed us to determine the main parameters of the Bio thermal waste treatment process, on the basis of which a research mathematical model is designed. The description of the process was based on basic equations describing the development and death of microorganisms, decomposition of organic matter, reduction of moisture content in the mixture, change in temperature of the compostable mixture and oxygen consumption during the Bio thermal disinfection process.

Gas production per day depending on the level of loading under thermophilic and mesophilic modes respectively

$$
\begin{aligned}
& \sum V_{\text {gas }}=1,4087 \cdot V_{\text {load }}^{0,8639} \\
& \sum V_{\text {gas }}=1,7437 \cdot V_{\text {load }}^{0,6932}
\end{aligned}
$$


The proportion of methane in biogas, depending on the loading level under thermophilic and mesophilic modes, respectively, is described by the equations

$$
\begin{aligned}
& M=56,131 \cdot V_{\text {load }}^{0,0245} \\
& M=65,1363 \cdot V_{\text {load }}^{-0,0591}
\end{aligned}
$$

Methane production, L/day, during mesophilic and thermophilic fermentation at different loading levels is described by the following equation

$$
\begin{aligned}
& P r_{\text {term }}=0,7919 \cdot V_{\text {load }}^{0,8874} \\
& P r_{\text {mes }}=1,1363 \cdot V_{\text {load }}^{0,5152}
\end{aligned}
$$

where $P r_{\text {term }}, P r_{\text {mes }}$ - methane production during thermophilic and mesophilic fermentation, respectively, per day;

load - loading level, grams of volatiles per liter of reactor volume per day.

Having constructed the dependence of the load on the required gas production, we get the dependence.

The dependence of the load on the required methane production under mesophilic and thermophilic modes is described by the following equations

$$
\begin{aligned}
& V_{\text {load,therm }}=0,9406 \cdot \operatorname{Pr}^{1,7717} \\
& V_{\text {load,therm }}=0,3041 \cdot \operatorname{Pr}^{1,1251}
\end{aligned}
$$

where $V_{\text {load., term }}, V_{\text {load., mes }}$ - loading level under thermophilic and mesophilic fermentation modes, respectively, grams of volatiles per liter of reactor volume per day;

$\mathrm{Pr}$ - methane production, $L$ per day.

The efficiency of methane production in mesophilic and thermophilic modes, L of methane per L of reactor volume per day, at different loading levels is described by the following equations

$$
\begin{gathered}
V_{G, \text { mes }}=0,3755 \cdot V_{\text {load }}^{0,5191} \\
V_{G, \text { term }}=0,2655 \cdot V_{\text {load }}^{0,8832}
\end{gathered}
$$

where $V_{g r \text {,mes }}$ - methane output in mesophilic mode, L of methane per L of reactor volume;

$V_{g r, \text { term }}$ - methane output in thermophilic mode, $L$ of methane per $\mathrm{L}$ of reactor volume; 
$V_{\text {load. }}$ - reactor load level, gr of volatiles per liter of reactor volume per day.

The amount of methane in biogas at different loading levels, in thermophilic and mesophilic modes is described by the following equations

$$
\begin{aligned}
& M Q_{\text {term }}=56,131 \cdot \operatorname{Load}^{0,0245} \\
& M Q_{\text {mes }}=65,352 \cdot \text { Load }^{-0,791}
\end{aligned}
$$

The total biomass energy under mesophilic and thermophilic modes is described by the following equations

$$
\begin{aligned}
& T E_{\text {mes }}=32,83 \cdot \text { Load }^{1,154} \\
& T E_{\text {therm }}=35,818 \cdot \text { Load }^{0435}
\end{aligned}
$$

where $T E_{m e s}, T E_{\text {therm }}$ is total biomass energy under mesophilic and thermophilic fermentation modes, respectively, $k J$ per day;

load. - loading level, grams of volatiles per liter of reactor volume per day.

The measure of energy conversion to methane during thermophilic and mesophilic fermentation is determined by the following equations

$$
\begin{aligned}
& M C_{\text {therm }}=99,958 \cdot \text { Load }^{-0,0374} \\
& M C_{\text {mes }}=104,37 \cdot \text { Load }^{-0,0912}
\end{aligned}
$$

The output of biogas depending on the content of organic dry substance, determined by the formula

$$
\text { Out }=0,2885 \cdot C D^{0,9821}
$$

where (Out - output, $C D$ - content of dry substance).

Based on the above and analyzed material proposed by the authors $[1,2,3,4,5,6]$, a mathematical model of the efficient use of energy of various types of biomass in the global energy economy is substantiated. The formed information and energy network of the fuel and bioenergy balance represents the energy economy in the form of a set of objects of various types that exchange energy flows. The stages of energy flow are represented in the network nodes. The lines connecting the nodes corresponded to the energy flows between the corresponding nodes. Each type of node in the energy balance information network has its own computing unit in the form of a system 
of nonlinear equations. A flowchart of this mathematical model was developed.

\section{Methods and techniques of processing pig manure.}

Methods and techniques of processing pig manure depend on the properties and composition of the raw material, as well as on the purposes of processing and the type of final products.

When choosing methods and techniques of processing pig manure they proceed from a scientifically based system of views, namely:

- pig manure has an energy potential due to the content of organic substances that can give off a significant amount of energy during their mineralization;

- pig manure is an integral part of the natural-natural chain "soil plant - animal - manure - soil", and should be used in this chain with the greatest effect;

- being a residue of processing plant photosynthesis products by animals, pig manure contains a large amount of organic substances, biogenous elements, trace elements, enzymes and vitamins;

- the presence of organic substances makes pig manure an ideal food for soil microflora, the vital activity of which ensures the normal course of biochemical processes in the soil, contributes to the formation of humus and the growth of soil fertility;

- biological features of pig manure exclude the possibility of its direct use as an organic fertilizer and should provide for compliance with sanitary and veterinary requirements;

- the final products of pig manure processing should not contain conditionally pathogenic microflora, worm eggs and their use should not cause diseases of people and animals, accumulation of harmful substances in the soil, lead to secondary weed infestation;

- the content of biogenous substances in pig manure can significantly reduce the use of mineral fertilizers, the production of which requires significant costs of raw materials and energy resources;

- feed application of pig manure should be considered as an auxiliary to the main types of feed, because it contains nutrients that are not absorbed during digestion (due to the physiological characteristics of pig digestion);

- manure processing is an important economic, managemental and environmental task, which should be considered from the point of view of a systematic approach. 
Based on the above, pig manure processing can be carried out in the following recent trends: obtaining organic fertilizer; fuel; feed; for the purpose of destruction or all of the enumerated together (fig. 1.). For this purpose, various methods of manure processing can be used, which can be divided into physical, chemical and biological.

Physical methods include: mechanical, thermal, and electrical [10]. Mechanical methods include a number of methods for processing liquid pig manure, such as settling, centrifugation, and filtration. The presented methods are aimed at dehydrating manure and dividing it into fractions. Methods of dividing pig manure into fractions and dehydrating liquid manure can be divided into natural and mechanical.

Natural separation of liquid manure occurs in horizontal and vertical settling tanks under the influence of the Earth's gravitational field. These equipment is simple, but natural settling of manure does not occur if its humidity is less $90 \%$. The capacity of settling tanks is low. They are also bulky and expensive. Nevertheless, this equipment is used in processing lines for separating livestock effluents.

Mechanical separation of liquid manure into fractions is the main type of separation of livestock effluents in large complexes. It is made using filtering and precipitation machines and apparatuses, the common disadvantage of which is the high humidity of the resulting solid fraction. Of the filter apparatuses and machines, filter-presses and vibrating screens (vibroshaker screens) are the most widely used. Mechanical methods can be considered as auxiliary, because they do not solve the problem of disinfection in the processing of pig manure and are energy-intensive. The resulting liquid and solid fractions require subsequent treatment by biological, chemical or thermal methods.

Thermal methods of manure processing include drying, sharp steam treatment, and evaporation. Drying can be carried out by both low-temperature and high-temperature methods. Low-temperature drying is carried out under natural conditions and allows you to stop the fermentation of manure. This method significantly reduces the humidity of manure without attracting significant energy costs, reduces unpleasant odors, but there is no guarantee of complete disinfection, and during the drying process there are significant losses of valuable components of manure. In recent years the method of dry- 
ing manure in special units under the influence of high temperatures has become widespread. Manure drying plants provide a product that meets sanitary and veterinary requirements, is convenient for transportation and application to the soil. However, the high cost of hightemperature drying is due to the price of fuel and lubricants and high initial costs, which do not allow this method of processing to be widely used.

Treatment with sharp steam is aimed at complete disinfection of manure. This method is energy-intensive and the manure at the outlet has a higher humidity, which is associated with its dilution by steam. The use of this method is possible in relatively narrow production conditions and in the case of outbreak.

The method of heat treatment of manure in autoclaves is used for disinfection of liquid pig manure, but requires a large energy consumption.

The group of electrical methods includes ultrahigh frequency current treatment, electroosmose treatment, electrochemical coagulation, electroflotation, and ultraviolet radiation treatment. These methods are not widely used due to the high cost of equipment, high energy costs and increased requirements for personnel.

One of the types of processing of liquid pig manure is chemical methods]. They prevent contamination and the release of odors into the environment, in addition, some chemical reagents destroy bacteria, including those that give rise to moist aerobic processes accompanied by the release of harmful gases. Chemical methods involve contact treatment with chemicals and are used only for disinfection of manure. A common disadvantage of chemical methods is that they require material and energy costs, as well as chemicals that cause a certain load on the environment. 


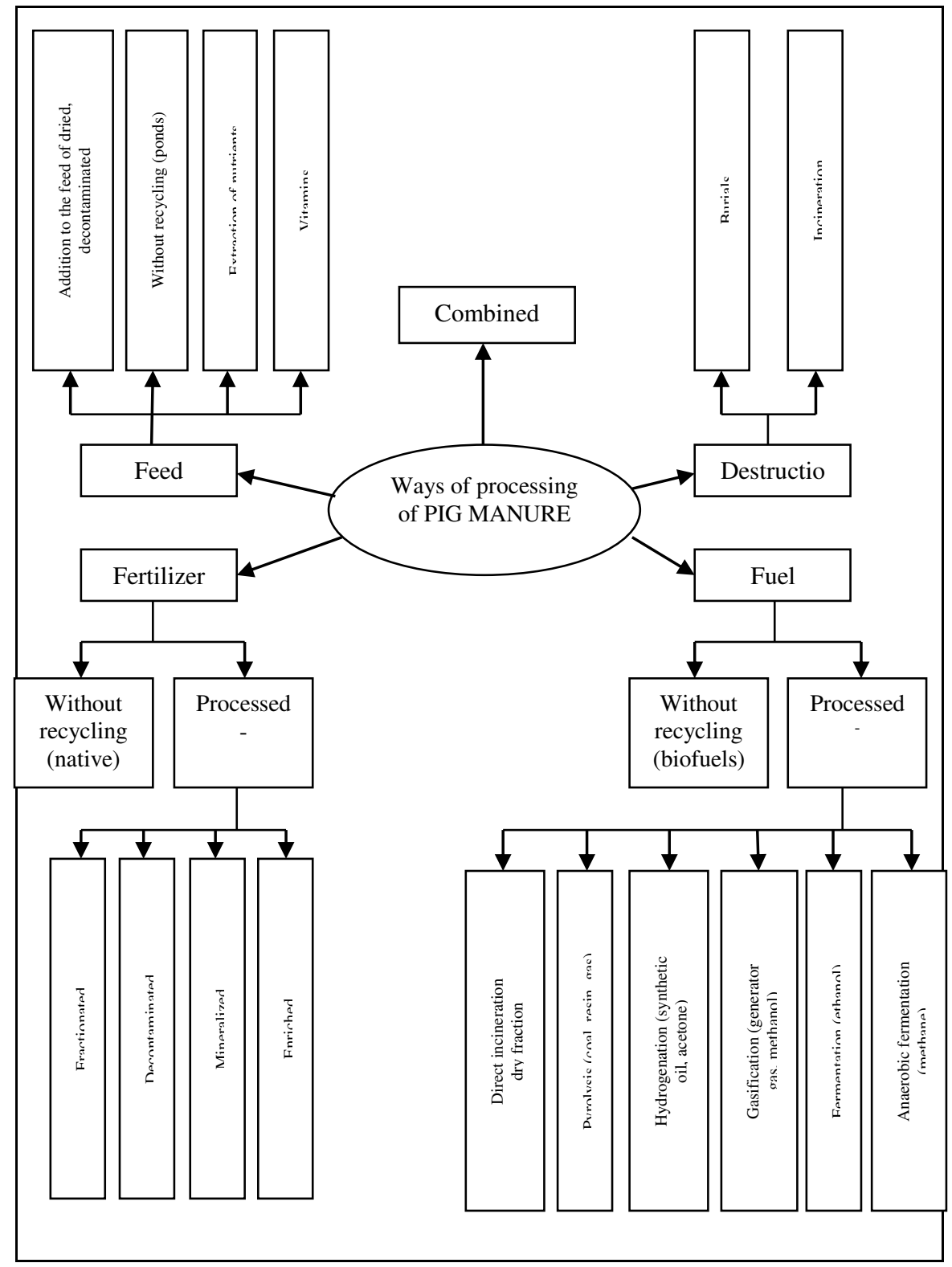

Fig. 1. Ways to process pig manure 
Biological methods are considered a promising area of pig manure processing. Biological methods are based on the biochemical destruction and mineralization of organic substances by microorganisms and are as close as possible to natural processes. At the same time, due to partial decomposition of organic substance, the content of pollution sources in liquid manure decreases, which turn into an insoluble or gaseous form. Biological methods are divided into natural and artificial. Natural methods are based on biochemical processes that occur in natural conditions - biological ponds, lagoons, soil and compost. Artificial methods are based on biochemical processes occurring under artificially created conditions - in aeration tanks, oxide trenches, methane tanks, anaerobic filters and other structures.

Depending on which groups of microorganisms are involved in the process, aerobic and anaerobic methods of biological treatment are distinguished.

Manure composting refers to aerobic biological decomposition processes. Disinfection of manure occurs during its decomposition and heating (up to $60{ }^{\circ} \mathrm{C}$ ) during the vital activity of thermophilic microorganisms. The main disadvantages of this method are the limited use in the climatic zones of the country, the duration of the process, significant losses of nutrients and the required large amount of filler.

The method of processing liquid pig manure in biological ponds has a relatively low processing cost. However, this method is long in time, requires the alienation of significant production areas, and there is a risk of freezing, increased stench, and contamination of ground water.

Aerobic treatment is used to intensify the process of decomposition and deposition of organic mass in pig manure. It occurs by aeration through pumping air from a compressor, or by using mechanical aerators, which, due to intensive mixing of liquid manure, ensure its contact with atmospheric oxygen, which creates favorable conditions for the vital activity of aerobic bacteria. But this method has a number of disadvantages: significant nitrogen losses, complexity and high cost of construction, high operating costs, as well as high energy costs for aeration and continuous mixing.

Anaerobic fermentation is considered a promising method. As a result of the fermentation process, organic substances contained in 
liquid manure undergo decomposition, with the formation of gaseous products in the form of a mixture of methane and carbon dioxide (biogas), [7]. At the same time, it is partially or completely decontaminated, dewormed, deodorized and devitalized. Various bioreactors are used for anaerobic fermentation: methane tanks and anaerobic filters. To ensure the process, it is necessary to maintain the temperature mode, the costs of which can be replenished by disposing of the released biogas. Anaerobic fermentation improves the fertilizing properties of manure as a result of mineralization of biogenous substances, almost without their loss to the environment. The method allows higher load rates than are possible during aerobic treatment, does not require the use of chemical reagents for the decomposition of organic matter; reduces the water-retaining capacity of manure. Anaerobic fermentation is the only method of discussed above that allows not only to cover the energy costs of conducting the process, but also to obtain an excessive amount of it. The resulting energy in the form of biogas is user-friendly, as it can be converted into thermal, electrical and mechanical energy. But this method practically does not reduce the volume and humidity of the treated manure.

Having considered the main methods and techniques of processing pig manure and manure effluents, we can draw the following conclusions:

- no method of processing liquid pig manure can completely solve the problem of disposal, so a combined solution is needed;

- the anaerobic fermentation method most meets the requirements, as it is the closest to natural conditions, which allows to get highquality organic fertilizer and an additional energy source in the form of biogas;

- to increase the efficiency of decomposition of organic matter, it is advisable to separate anaerobic treatment of the liquid and solid phases of pig manure in special bioreactors;

- it is necessary to improve the method of anaerobic treatment of pig manure and effluents. 


\section{The anaerobic treatment process of pig manure.}

Anaerobic treatment is a multi-stage process carried out with the participation of various microorganisms, and proceeds in a certain sequence. There are four interrelated stages: the stage of enzymatic hydrolysis, the stage of acid formation, the acetogenic stage and the methanogenic stage.

Depending on the temperature required for the anaerobic treatment process, the following fermentation modes are distinguished: psychrophilic $\left(10-25^{\circ} \mathrm{c}\right)$, mesophilic $\left(30-35^{\circ} \mathrm{C}\right)$, thermotolerant (40$\left.45^{\circ} \mathrm{C}\right)$ and thermophilic $\left(50-60^{\circ} \mathrm{C}\right)$. Two temperature modes, mesophilic and thermophilic, have found the greatest practical application, while mesophilic is considered less energy-intensive. Also, Davids V. E. points out that the intensity of the process under the mesophilic mode is not inferior to the intensity under the thermophilic mode, and the depth of mineralization of organic substances is greater. This is due to the better formation of the aggregated form of biomass.

Technologies of anaerobic processing of pig manure are classified into three main systems. There are flow-through (continuous) systems with alternating use of reactors (periodic) and a system with gas and sludge accumulation (accumulative), which differ significantly in labor costs, maintenance and servicing requirements, as well as in use.

In the flow-through system, the substrate is loaded into the reactor continuously or after short periods of time, removing the appropriate volume of sludge. The always constant volume of the substrate is calculated in accordance with the time of the mass stay in the reactor specified by hydraulic calculations.

A system with alternating use of reactors is characterized by an intermittent process that occurs in at least two reactors of the same size and shape. In the case of daily loading of fresh substrate, the reactors are filled with fresh substrate when a certain amount of sludge is formed and emptied after the specified fermentation period has elapsed so that only seed sludge remains in them.

The gas and sludge storage system is designed with only one liquid reactor. The latter plays the role of a fermentation chamber and accumulates sludge until it is taken out into the field. Therefore, the reactor is never completely emptied, the remaining sludge serves as an ignition for a new portion of the substrate. With a new cycle of 
operation, the maximum production of biogas is achieved after a significant time has elapsed.

In systems with alternating use of reactors and systems with accumulation of gas and sludge, gas production occurs periodically. In addition, this technology requires an increase in the volume of reactors for processing. Their advantage is that they do not require much attention when operating during the day, and they can be loaded with large waste.

Continuous operation of the reactors ensures gas output throughout the entire period of operation. By ensuring a constant concentration of organic matter capable of fermentation, an optimal fermentation temperature and uniform mixing of the mass, it is possible to obtain the maximum gas yield during a continuous gas formation process. The most effective in operation are horizontal fermenters of continuous action. The raw material entering from one side passes through the "maximum fermentation" zone, where the bacteria have the greatest activity, and then exits from the other end of the structure. In case of unsatisfactory fermentation results, the material can be sent for recycling.

Process schemes of single - stage and two-or multi-stage fermentation have also become widespread. Single-stage fermentation is used in low-load and high-load methane tanks. Low-load reactors have a fermentation time of up to 50 days and operate almost without mixing with little heating, so they have large volumes and high construction costs. High-load reactors are already equipped with good heating and mixing, as well as provide for continuous loading or short intervals between loads. In high-load reactors, sediment and entrapped water do not stratify, and therefore some process schemes provide for the use of second-stage reactors, that is, the transition to two-stage fermentation. Two-and multi-stage fermentation is based on the division into the stage of intensive fermentation with rapid release of biogas (Stage 1) and the stage of process attenuation, at which gas release stops and sediment and entrapped water stratification occurs (Stage 2). In multi-stage fermentation, post-fermentation and stratification are carried out in several successively located tanks. The use of two - and multi-stage fermentation reduces the vol- 
ume of fermented sludge supplied for dehydratation and reduces the cost of building sludge drying beds. However, step-by-step fermentation does not provide significant advantages in terms of biogas yield compared to a single-stage process with equal volumes of methane tanks. In Russia, stage fermentation has not found application, because of the great difficulties of their operation in the formation of a dense pop-up crust and filling of the cone with sand at the second stage.

The main element of any process of anaerobic manure treating is biogas plants of various designs. Biogas plants can be divided into solid-phase (methane tanks) and liquid-phase anaerobic bioreactors (anaerobic filters). Anaerobic treatment in methane tanks is carried out at a humidity of 90-93\% with an exposure of 5-50 days and is traditional for processing solid (dispersed phase) pig manure. The liquid (dispersed) phase obtained after separation has a high humidity of 97-99.5\% and existing solutions provide exclusively for aerobic oxidation, which has significant disadvantages. A promising area for processing the liquid fraction of pig manure is the use of liquid-phase anaerobic filters.

According to the classification given by Danylovych D. A. and Mongait L. I., liquid-phase anaerobic reactors of the second generation can be divided into the following types: anaerobic filters - reactors with an ascending flow (AF-reactor); reactors with a fixed (bio) film and an incident stream (IS-reactor); reactors with an extended (pseudo - liquefied) layer (PS-reactor); hybrid reactors, which are a combination of IS-and AF-reactor designs (ISF-reactor). These structures are most recommended for cleaning high-flow rates of highly concentrated livestock effluents. Analysis of the operation of the reactors showed that the load on PS - reactors can be up to $35 \mathrm{~kg}$ of $\mathrm{COD} / \mathrm{m}^{3}$ a day, they are quite sensitive to the content of suspended particles and the liquefaction of the carrier layer requires repeated recirculation of the treated flow using pumping equipment. At IS reactors with high nitrogen concentrations and complex effluents composition, poor granulation of the musk layer is noted. The AF 
reactor has a load of up to $25-30 \mathrm{~kg} \mathrm{COD} / \mathrm{m}^{3}$ a day, and resistant to cleaning, but has a disadvantage associated with the danger of colmation and the formation of better channels of the duct. The ISF reactor has the lowest load of about $6 \mathrm{~kg} \mathrm{COD} / \mathrm{m}^{3}$ a day. DF-reactor is less whimsical, the risk of colmation is less and the accumulation of suspensions at the bottom of the reactor does not occur, but it shows good performance at loads up to $15-20 \mathrm{~kg} \mathrm{COD} / \mathrm{m}^{3}$ a day and amount of biomass retained is less than in AF. Similarly, compared to $\mathrm{AF}$, the DF-reactor requires careful selection of the loading material. Hardware design research showed that it is advisable to arrange AF reactors in the form of vertical columns with the passage of treated effluents from bottom to top. This ensures the accumulation and maintenance of the required number of microorganisms and facilitates the removal of biogas, while different populations of microorganisms are arranged spatially in a sequence corresponding to the phases of anaerobic fermentation.

Analysis of technologies and equipment for anaerobic processing of pig manure allows us to accept the following conclusions:

- for anaerobic fermentation, the mesophilic fermentation mode and continuous reactor operation mode are more economical;

- of the liquid - phase anaerobic bioreactors, a vertical AF reactor with an upward flow is more used for processing the liquid phase of pig manure and effluents.

The main reason that hinders the use of non-traditional energy sources for energy purposes in Ukraine is that the resulting energy has a high cost, that is, it is relevant to search for processes and solutions that are characterized by low capital and operating costs, as well as low cost of energy products obtained through the production of related products. This is the technology of the anaerobic fermentation process of biomass, which makes it possible to produce fuel gas with a relatively high calorific value, as well as to obtain high-quality fertilizers, due to the implementation of which an additional profit can be obtained. 
The necessary data were determined on the basis of the performed studies of the process of anaerobic fermentation of biomass at the industrial livestock complex of the Zaporizhstal LLC at the existing biogas plant described in. The total number of livestock on the farm is 10,000 pigs.

Based on control measurements, it was found that 68 liters of liquid biomass are generated daily from one livestock. The total volume of biomass is: in the winter season $-75 \mathrm{~m}^{3} /$ day (from 10,000 pigs), in the summer season $-65 \mathrm{~m}^{3} /$ day (from 8050 pigs) [7].

The content of dry matter formed daily from excrement and litter is $6.2-6.3 \mathrm{~kg}$ per pig, and the average content of organic substances is $5 \mathrm{~kg} / \mathrm{pig}$. Taking this into account, the daily produced mass of organic matter is $5500 \mathrm{~kg} / \mathrm{day}$ in the winter season and $4750 \mathrm{~kg} / \mathrm{day}$ in the summer season.

The specific quantity of total biogas attributed to 1 ton of organic matter, according to the results of research, was assumed to be equal to $300 \mathrm{~m}^{3} / \mathrm{t}$ in the winter season.

In the summer season, when only $65 \mathrm{~m}^{3}$ of biomass is collected per day, the projected volume of the chamber allows you to ferment liquid biomass for more than 25 days, and less heat is required to maintain the temperature. Therefore, despite the smaller amount of organic matter, it is possible to obtain a larger amount of commercial gas, that is, $350 \mathrm{~m}^{3}$ from one ton of organic matter.

In the first series of tests, laboratory measurements of the biogas yield and the rate of its formation in the thermal chamber were carried out under mesophilic $\left(35^{\circ} \mathrm{C}\right)$ and thermophilic $\left(55^{\circ} \mathrm{C}\right)$ modes. The duration of the tests was assumed to be 35 days. The amount of dry matter, organic matter content, $\mathrm{pH}$ value, and volume weight were determined in a chemical laboratory.

The total amount of gas released was measured once a day. The measurement results were analyzed every 5 days. Processing of the obtained results was carried out according to generally accepted 
methods. The specific quantity of biogas was determined in liters per $1 \mathrm{~kg}$ of organic matter.

Table 1 shows the characteristics of liquid biomass of livestock used in experimental studies in the mesophilic fermentation mode.

Table 1

Characteristics of liquid livestock biomass in mesophilic fermentation mode

\begin{tabular}{c|c|c|c|c}
\hline Indicators of & \multicolumn{3}{|c|}{ Test number } & \multirow{2}{*}{ Average value } \\
\cline { 2 - 4 } fermented biomass. & 1 & 2 & 3 & 5.3 \\
\hline Volume, L & 6.0 & 5.0 & 5.0 & 0.477 \\
\hline $\begin{array}{c}\text { Dry matter content, } \\
\mathrm{kg}\end{array}$ & 0.582 & 0.425 & 0.425 & 8.9 \\
\hline $\begin{array}{c}\text { Organic matter } \\
\text { content, kg } \\
\%\end{array}$ & 9.7 & 8.5 & 8.5 & 0.383 \\
\hline pH value & 7.8 & 0.340 & 0.340 & 7.2 \\
\hline Volume weight, g / L & 6.8 & 6.8 & 6.8 & - \\
\hline
\end{tabular}

Indicators of liquid biomass used in the study in the thermophilic fermentation mode are shown in Table 2.

Table 2

Characteristics of liquid livestock biomass in thermophilic fermentation mode

\begin{tabular}{c|c|c|c|c}
\hline Indicators of & \multicolumn{3}{|c|}{ Test number } & \multirow{2}{*}{ Average value } \\
\cline { 2 - 4 } fermented biomass & 4 & 5 & 6 & 5.3 \\
\hline Volume, L & 6.0 & 5.0 & 5.0 & \\
\hline Dry matter content, & & & & 0.435 \\
$\mathrm{~kg}$ & 0.454 & 0.425 & 0.425 & 8.2 \\
$\%$ & 7.57 & 8.53 & 8.5 & 0.348 \\
\hline Organic matter & & & & 6.57 \\
content, kg & 0.636 & 0.341 & 0.340 & - \\
$\%$ & 6.1 & 6.82 & 6.80 & 1008 \\
\hline pH value & 7.1 & 6.8 & 7.0 & \\
\hline Volume weight, g/L & 1006 & 1010 & 1018 & \\
\hline
\end{tabular}

Determination of the total biogas yield and gas release rate.

Based on the totality of data obtained as a result of tests conducted at laboratory installations with thermal chambers during periodic fermentation, the amount of biogas formed from liquid livestock biomass was determined. Indicators that characterize the yield of biogas during 35-day fermentation under the mesophilic mode are shown in Table 3. 
Table 3

Indicators that characterize the yield of biogas during 35-day fermentation under the mesophilic mode

\begin{tabular}{c|c|c|c|c|c}
\hline \multirow{2}{*}{$\begin{array}{c}\text { Fermentation } \\
\text { period, days }\end{array}$} & \multicolumn{4}{|c|}{ Amount of biogas released, L } & \multirow{2}{*}{$\begin{array}{c}\text { Amount of gas, } \\
\text { relative to } 1 \mathrm{~kg} \text { of } \\
\text { org. matter, L/kg }\end{array}$} \\
\cline { 2 - 4 } $\begin{array}{c}\text { Ond number } \\
\text { average }\end{array}$ & $\begin{array}{c}|c| \\
\text { Test }\end{array}$ & 2 & 3 & 27.96 & 73.0 \\
\hline 5 & 17.89 & 39.80 & 26.68 & 27.3 & 111.3 \\
\hline 10 & 22.58 & 64.83 & 40.48 & 42.63 & 159.4 \\
\hline 15 & 25.66 & 93.92 & 63.53 & 61.04 & 194.4 \\
\hline 20 & 29.94 & 113.72 & 79.67 & 74.67 & 216.5 \\
\hline 25 & 37.66 & 126.88 & 84.23 & 82.92 & 231.2 \\
\hline 30 & 39.16 & 137.40 & 89.08 & 88.55 & 247.1 \\
\hline 35 & 42.6 & 148.58 & 92.76 & 94.65 & \\
\hline
\end{tabular}

The amount of biogas obtained during 35-day fermentation under the thermophilic mode is shown in Table 4.

Table 4

Indicators that characterize the yield of biogas during 35-day fermentation in thermophilic model

\begin{tabular}{c|c|c|c|c|c}
\hline \multirow{2}{*}{$\begin{array}{c}\text { Fermentation } \\
\text { period, days }\end{array}$} & \multicolumn{4}{|c|}{ Test number } & \multirow{2}{*}{$\begin{array}{c}\text { Amount of } \\
\text { gas, relative } \\
\text { to 1 kg of org. } \\
\text { matter, L/kg }\end{array}$} \\
\cline { 2 - 5 } & 4 & 5 & 6 & On average & 85.6 \\
\hline 5 & 17.64 & 8.81 & 63.16 & 29.87 & 127.6 \\
\hline 10 & 36.30 & 19.43 & 77.47 & 44.40 & 183.5 \\
\hline 15 & 77.30 & 31.08 & 83.24 & 63.37 & 239.4 \\
\hline 20 & 117.78 & 39.11 & 93.8 & 83.32 & 279.1 \\
\hline 25 & 138.04 & 45.95 & 107.34 & 97.11 & 309.2 \\
\hline 30 & 154.78 & 50.17 & 117.87 & 107.60 & 329.5 \\
\hline 35 & 164.72 & 53.26 & 126.09 & 114.69 & \\
\hline
\end{tabular}

When designing a biogas plant for anaerobic processing of liquid biomass, it is necessary to know the change in the rate of gas formation, that is, the amount of gas formed daily from $1 \mathrm{~kg}$ of organic matter. The gas formation rates were obtained as a result of tests performed in mesophilic and thermophilic fermentation modes. Knowledge of the pattern of speed reduction is necessary when choosing the fermentation time.

Taking the amount of gas produced during 35-day fermentation as $100 \%$, we investigated how the amount of gas decreases every 5 days. 
Analyzing the data in Table 6, we can conclude that about $87 \%$ of the amount of biogas formed in 35 days in the mesophilic mode was obtained already on the 25th day of treatment. When the fermentation time increases by 10 days, the amount of gas increases by only $13 \%$. Because the amount of biogas released is affected by the fermentation temperature.

It can be concluded that already on the 25th day, with the thermophilic mode, approximately $30 \%$ more gas is obtained than with the mesophilic one.

Hence, it is necessary that to obtain the same total yield of biogas in the thermophilic mode, a fermentation chamber of a smaller volume would be required than in the mesophilic mode, but due to the higher fermentation temperature, the heat consumption for the process's own needs in the thermophilic mode increases by 1.5 times (as a percentage of the thermal equivalent of the biogas released), while the amount of commercial biogas is almost the same with the mesophilic mode.

Environmental protection as a result of anaerobic biomass treatment is assessed by a decrease in the number of malignant pathogenic bacteria, as well as a change in COC (chemical oxygen consumption). Based on bacteriological studies, the paper determines the dependences of the number of malignant bacteria on the temperature and duration of anaerobic treatment, as well as the values of these parameters, at which the bacterial number during biomass treatment decreases to such a value when the risk of contamination of the environment becomes minimal, this was studied in $[2,3,4,5,6]$.

In addition to laboratory tests, practical observations were made on the intensity of the event during the storage of fermented liquid biomass.

The tasks of the research also included monitoring changes in nutrients in fermented biomass.

Experiences were performed for mesophilic and thermophilic fermentation modes. Liquid biomass samples were taken in a filled chamber and then every 3 days.

Results of studies of bacteriological properties of liquid biomass in the process of its fermentation. 
Both the literature data and our measurements confirm the fact that untreated liquid biomass should be considered a material of malignant bacteria.

Bacteriological studies were conducted on a laboratory machine with a water bath. Liquid biomass sampling are made at the beginning of fermentation, then every 3-4 days, and finally on Day 12 . The bacteriological index was calculated as the arithmetic mean value of the bacteria count: in the mesophilic zone at $30^{\circ} \mathrm{C}$ and $40^{\circ} \mathrm{C}$, in the thermophilic zone - at $55^{\circ} \mathrm{C}$ and $60^{\circ} \mathrm{C}$.

The effect of anaerobic fermentation on the reduction of malignant bacteria was determined by a change in the coliform, streptococcus faccalis bacteria count. In addition, the presence of salmonella was monitored in each sample.

The results of bacteriological studies are shown in Tables 5 and 6 .

Table 5

Results of coliform bacteria study

\begin{tabular}{|c|c|c|c|c|c|c|c|c|}
\hline \multirow{3}{*}{$\begin{array}{l}\text { Fermentat } \\
\text { ion time }\end{array}$} & \multicolumn{8}{|c|}{ Coliform bacteria, U/100 ml. } \\
\hline & \multicolumn{2}{|c|}{ mesophilic mode } & \multirow{2}{*}{$\begin{array}{l}\text { average } \\
\text { value }\end{array}$} & \multirow{2}{*}{$\%$} & \multicolumn{2}{|c|}{ Thermophilic mode } & \multirow{2}{*}{$\begin{array}{l}\text { average } \\
\text { value }\end{array}$} & \multirow{2}{*}{$\%$} \\
\hline & $350 \mathrm{C}$ & $400 \mathrm{C}$ & & & $550 \mathrm{C}$ & $600 \mathrm{C}$ & & \\
\hline 0 & $4.0 \cdot 106$ & $4.0 \cdot 106$ & $4.0 \cdot 106$ & 100 & $9.8 \cdot 106$ & $13.5 \cdot 106$ & $\begin{array}{c}11.6 \cdot 10 \\
6\end{array}$ & 100 \\
\hline 2 & - & - & - & - & $2.0 \cdot 106$ & - & $2.6 \cdot 106$ & 17 \\
\hline 4 & - & - & - & - & - & $1.0 \cdot 105$ & $1.0 \cdot 105$ & 0.8 \\
\hline 6 & $4.0 \cdot 104$ & $3.0 \cdot 104$ & $3.5 \cdot 104$ & 0.88 & $1.0 \cdot 104$ & - & $1.0 \cdot 104$ & 0.08 \\
\hline 8 & $1.0 \cdot 104$ & $1.0 \cdot 104$ & $1.0 \cdot 104$ & - & $8.0 \cdot 103$ & - & $8.0 \cdot 103$ & - \\
\hline 10 & - & - & - & - & $4.1 \cdot 103$ & - & $4.1 \cdot 103$ & - \\
\hline 12 & $1.0 \cdot 103$ & $6.0 \cdot 103$ & $3.5 \cdot 103$ & - & - & - & - & - \\
\hline
\end{tabular}

Table 6

Results of studies of the bacterium streptococcus faccalis

\begin{tabular}{c|c|c|c|c|c|c|c|c}
\hline \multirow{2}{*}{$\begin{array}{c}\text { Fermentation } \\
\text { time }\end{array}$} & \multicolumn{7}{|c|}{ Streptococcus faccalis bacteria, U/100 ml. } \\
\cline { 2 - 9 } & $350 \mathrm{C}$ & $400 \mathrm{C}$ & $\begin{array}{c}\text { average } \\
\text { value }\end{array}$ & $\%$ & $550 \mathrm{C}$ & $600 \mathrm{C}$ & $\begin{array}{c}\text { average } \\
\text { value }\end{array}$ & $\%$ \\
\hline 0 & $2.0 \cdot 106$ & $2.0 \cdot 106$ & $2.0 \cdot 106$ & 100 & $2.0 \cdot 106$ & $2.0 \cdot 106$ & $2.0 \cdot 106$ & 100.0 \\
\hline 4 & - & - & - & - & $5.0 \cdot 103$ & $2.0 \cdot 103$ & $3.0 \cdot 103$ & 0.15 \\
\hline 6 & $8.0 \cdot 104$ & $4.0 \cdot 104$ & $6.5 \cdot 104$ & 3 & $4.0 \cdot 103$ & $4.0 \cdot 102$ & $2.0 \cdot 103$ & - \\
\hline 8 & $2.0 \cdot 104$ & $1.4 \cdot 104$ & $1.7 \cdot 104$ & 0.85 & $3.6 \cdot 103$ & - & - & - \\
\hline 12 & $1.0 \cdot 103$ & $2.0 \cdot 103$ & $1.5 \cdot 103$ & - & - & - & - & - \\
\hline
\end{tabular}

Mathematical processing of experimental data showed that the number of bacteria in the fermentation process varies exponentially. The general form of an adapted dependency has the form 


$$
X=d \cdot e^{-B t}
$$

where $X$ - number of bacteria;

$d$ - regression constant;

$t$ - processing time;

$B$ - calculated coefficient.

As a result of mathematical processing of experimental data the empirical dependences of the bacteria count of coliform on the duration of fermentation were obtained:

- $\quad$ in mesophilic mode

$$
X=4 \cdot 10^{6} \cdot e^{-0,7085 t}
$$

- $\quad$ in thermophilic mode

$$
X=11 \cdot 10^{6} \cdot e^{-0,9896 t}
$$

The dependence of the bacteria count of streptococcus faccalis on the duration of fermentation has the expression:

- $\quad$ in mesophilic mode

$$
y^{\prime}=2 \cdot 10^{6} \cdot e^{-0,5818 \mathrm{t}}
$$

- $\quad$ in thermophilic mode

$$
y^{\prime}=2 \cdot 10^{6} \cdot e^{-1,38105 t}
$$

The decrease in the bacteria count during fermentation is shown in Table 7.

Table 7

The decrease in the bacteria count during

\begin{tabular}{c|c|c|c|c|c|c|c|c}
\hline \multirow{2}{*}{ Bacterial species } & \multicolumn{7}{c}{ Days } \\
\cline { 2 - 9 } & 0 & 2 & 4 & 6 & 8 & 10 & 12 \\
\hline \multirow{2}{*}{ coliform } & $350 \mathrm{C}$ & $4.0 \cdot 106$ & $9.7 \cdot 105$ & $2.3 \cdot 105$ & $5.7 \cdot 104$ & $1.4 \cdot 104$ & $3.3 \cdot 103$ & 812 \\
\cline { 2 - 10 } & $550 \mathrm{C}$ & $11.6 \cdot 106$ & $1.6 \cdot 106$ & $2.2 \cdot 105$ & $3.1 \cdot 104$ & $4.2 \cdot 103$ & 600 & 81 \\
\hline \multirow{2}{*}{$\begin{array}{c}\text { streptococ } \\
\begin{array}{c}\text { cus } \\
\text { faccalis }\end{array}\end{array}$} & $350 \mathrm{C}$ & $2.0 \cdot 106$ & $6.25 \cdot 105$ & $1.96 \cdot 104$ & $1.9 \cdot 104$ & $1.9 \cdot 104$ & $6.0 \cdot 103$ & $1.9 \cdot 103$ \\
\cline { 2 - 9 } & $550 \mathrm{C}$ & $2.0 \cdot 106$ & $1.27 \cdot 105$ & $8.0 \cdot 103$ & 506 & 32 & 3 & - \\
\hline
\end{tabular}

In the thermophilic mode, the decrease in the bacteria count occurs faster than in the mesophilic mode, but in both modes, the number of bacteria in the fermented biomass reaches its minimum value after 12 days of fermentation. Its presence was not detected in samples of liquid biomass contaminated with salmonella after anaerobic treatment.

Results of studies on the fertilizing properties of fermented biomass. 
During the study of the composition of liquid biomass, the content of dry and organic matters, the content of DO (dissolved oxygen), the $\mathrm{pH}$ value, the rate of sediment formation were measured, and the threshold was controlled as described in $[10,11]$.

The percentage change in the studied parameters was calculated using the following formula

$$
P=1-\frac{(100-A) \cdot B}{(100-B) \cdot A}
$$

where $P$ - percentage reduction of the studied parameter, $\%$;

$A$ - percentage of the studied parameter in untreated biomass, $\%$;

$B$ - percentage of the studied parameter in fermented biomass, $\%$.

The studies were conducted with samples treated at four temperature values, the results of the studies are shown in Table 8.

Table 8

The results of the studies

\begin{tabular}{|c|c|c|c|c|c|}
\hline $\begin{array}{l}\text { Mode tempe- } \\
\text { rature }\end{array}$ & $\begin{array}{c}\text { Chara-cteristics of } \\
\text { biomass }\end{array}$ & $\begin{array}{l}\text { Untreated } \\
\text { biomass }\end{array}$ & Ferme-nted biomass & Days & $\begin{array}{l}\text { of fermenta- } \\
\text { tion number }\end{array}$ \\
\hline \multirow{7}{*}{$35^{\circ} \mathrm{C}$} & Dry matter, $\%$ & 3.83 & 3.13 & \multirow{7}{*}{12} & 19 \\
\hline & Organic matter, $\%$ & 2.57 & 2.05 & & 21 \\
\hline & Nitrogen, $\%$ & 0.12 & 0.12 & & 0 \\
\hline & Phosphorus, \% & 0.036 & 0.034 & & 6 \\
\hline & Potassium, $\%$ & 0.037 & 0.036 & & 4 \\
\hline & $\mathrm{pH}$ & 7.2 & 7.3 & & - \\
\hline & $\mathrm{CSA}, \mathrm{mg} / \mathrm{L}$ & 31515 & 17262 & & 55 \\
\hline \multirow{7}{*}{$40^{\circ} \mathrm{C}$} & Dry matter, $\%$ & 1.10 & 0.93 & \multirow{7}{*}{9} & 16 \\
\hline & Organic matter, $\%$ & 0.85 & 0.71 & & 17 \\
\hline & Nitrogen, $\%$ & 0.12 & 0.11 & & 8 \\
\hline & Phosphorus, \% & 0.049 & 0.048 & & 3 \\
\hline & Potassium, $\%$ & 0.032 & 0.030 & & 7 \\
\hline & $\mathrm{pH}$ & 7.1 & 7.1 & & - \\
\hline & $\mathrm{CSA}, \mathrm{mg} / \mathrm{L}$ & 12978 & 84413 & & 37 \\
\hline \multirow{7}{*}{$55^{\circ} \mathrm{C}$} & Dry matter, $\%$ & 5.80 & 4.50 & \multirow{7}{*}{10} & 23 \\
\hline & Organic matter, $\%$ & 4.29 & 3.09 & & 28 \\
\hline & Nitrogen, $\%$ & 0.15 & 0.14 & & 7 \\
\hline & Phosphorus, $\%$ & 0.030 & 0.030 & & 0 \\
\hline & Potassium, $\%$ & 0.051 & 0.049 & & 5 \\
\hline & $\mathrm{pH}$ & 7.1 & 7.4 & & - \\
\hline & $\mathrm{CSA}, \mathrm{mg} / \mathrm{L}$ & 41988 & 26895 & & 38 \\
\hline
\end{tabular}




\begin{tabular}{|c|c|c|c|c|c|}
\hline \multirow{7}{*}{$60^{\circ} \mathrm{C}$} & Dry matter, \% & 2.0 & 1.51 & \multirow{7}{*}{6} & 25 \\
\hline & Organic matter, $\%$ & 1.54 & 1.16 & & 25 \\
\hline & Nitrogen, $\%$ & 0.11 & 0.10 & & 9 \\
\hline & Phosphorus, $\%$ & 0.076 & 0.069 & & 10 \\
\hline & Potassium, \% & 0.040 & 0.038 & & 5 \\
\hline & $\mathrm{pH}$ & 7.2 & 7.2 & & - \\
\hline & $\mathrm{CSA}, \mathrm{mg} / \mathrm{L}$ & 33058 & 22502 & & 47 \\
\hline
\end{tabular}

Content $N^{P K}$ in fresh and fermented liquid biomass (under periodic and continuous modes) is presented in Tables 9 and 10, respectively.

Table 9

Content $\mathrm{N}^{\mathrm{PK}}$ in fresh and fermented liquid biomass under periodic mode

\begin{tabular}{c|c|c|c|c|c|c|c|c|c|c}
\hline $\begin{array}{c}\text { Type of } \\
\text { biomass }\end{array}$ & $\begin{array}{c}\text { Dry } \\
\text { matter, } \\
/ \mathrm{kg}\end{array}$ & $\begin{array}{c}\text { Organic } \\
\text { matters }\end{array}$ & $\mathrm{N}$ & $\mathrm{P}$ & $\mathrm{K}$ & $\mathrm{N}$ & $\mathrm{P}$ & $\mathrm{K}$ & $\begin{array}{c}\text { Total } \\
\text { reage } \\
\mathrm{nts}\end{array}$ \\
\hline \multicolumn{3}{c}{} & \multicolumn{2}{|c|}{$\mathrm{g} / \mathrm{kg}$ of dry matter } & \multicolumn{3}{|c|}{$\mathrm{kg} / \mathrm{m}^{3}$ of liquid bio- } \\
mass
\end{tabular}

Table 10

Content $\mathrm{N}^{\mathrm{PK}}$ in fresh and fermented liquid biomass under continuous mode

\begin{tabular}{|c|c|c|c|c|c|c|c|c|c|}
\hline $\begin{array}{l}\text { Type of } \\
\text { biomass }\end{array}$ & $\begin{array}{c}\text { Dry } \\
\text { matter, g } \\
/ \mathrm{kg}\end{array}$ & $\begin{array}{c}\text { Organic } \\
\text { matters }\end{array}$ & $\mathrm{N}$ & $\mathrm{P}$ & K & $\mathrm{N}$ & $\mathrm{P}$ & K & $\begin{array}{l}\text { Total } \\
\text { reagents }\end{array}$ \\
\hline & & & \multicolumn{3}{|c|}{$\mathrm{g} / \mathrm{kg}$ of dry matter } & \multicolumn{3}{|c|}{$\begin{array}{c}\mathrm{kg} / \mathrm{m}^{3} \text { of liquid } \\
\text { biomass }\end{array}$} & \\
\hline Fermented & 41 & 690 & 70 & 21 & 39 & $\begin{array}{l}2 . \\
8\end{array}$ & 0.84 & 1.5 & 5.14 \\
\hline
\end{tabular}

Analysis of the study results showed that the decrease in organic matter in liquid biomass is proportional to the fermentation time. Two parameters - biological $\mathrm{BOD}_{5}$ (biochemical oxygen demand for 5 days) and chemical oxygen demand COD were used to quantify organic matter.

The results of reducing the COD value during fermentation are shown in Table 4. After 15 days of fermentation, COD decreases by $40 \%$. The reduction of organic matter and COD value during fermentation, in turn, reduces the harmful impact of liquid biomass on the environment, but the COD value equal to $75 \mathrm{mg} / \mathrm{l}$ provided for by water management standards is not achieved.

\section{General conclusions}


1. This paper analyzes the heat ratios obtained during anaerobic fermentation of biomass with a wide range of methane contained in biogas at different levels of bioreactor loading and under different temperature settings.

2. A mathematical model and algorithm for studying the efficient use of biomass energy in the energy sector of the agro-industrial complex are developed and justified, which make it possible to choose a rational layout of energy equipment, determine the optimal structure of energy resources consumed and the working cost of energy generated.

3. For a more correct assessment of the energy efficiency of an anaerobic reactor, it seems desirable to consider all factors by mass characteristics.

4. Based on the conducted studies, it can be concluded that after fermentation, more than $50 \%$ of the dry matter of liquid biomass deposits within 3 days. The odour of liquid biomass decreases after fermentation, and this is due to the rapid decomposition of primarily biologically unstable compounds (carbon, proteins, etc.). The reduction in odour depends on the fermentation time; as the fermentation time increases, the odour threshold decreases.

\section{List of references used}

1. Kuris Yu. V. Improving heat engineering and process performance of biogas combustion in heat generating equipment: dissertation for the degree of candidate of technical sciences, NUKhT, Kyiv, 2007.

2. Tkachenko S.I., Stepanov D.V., Kryuchkov Ye.M., Kuris Yu.V., Litvishkov I.V. Peculiarities of water heating boiler operation on biogas. / / Fahovy journal "Scientific Journal of the Kyiv Polytechnic Institute", Kyiv - №1. - 2006. - pp. 2529.

3. Kuris Yu. V., Tkachenko S. I. Analysis of the effectiveness of the global energy and environmental use of biomass // Professional Journal "Industrial Electricity". Kyiv, - № 5. - 2008. - pp. 35-41.

4. Kuris Yu.V., Kryuchkov E. N. Analysis of the energy balance of production-livestock complex of PJSC "Zaporizhstal" using a bioenergy plant // Collection of conferences "Biotechnology: Education, Science" - NTU KPI. - 2003. pp. 141143.

5. Kuris Yu.V., Tkachenko S. I. Systematization of the World Energy and Environmental Use of Biomass. // Specialized Journal "Energy News.", Kyiv, - № 1. 2009. - pp. 19-27.

6. Kuris Yu.V., Levitskaya I. N. The study of biogas production during anaerobic digestion of carbohydrates, fats and proteins // Proceedings of the interuniversi- 
ty scientific conference ZSEA "Modern environmental problems - IV" - Zaporozhye, - 2008. - pp. 37-39.

7. Kuris Yu.V., Yarmosh V.V., Olshansky S. N., Litvishkov I. V. General characteristics of methanogenesis and justification of technological schemes of biogas production. // Specialized Journal "Power Engineering and Electrification." Kyiv, - № 3. - 2009. - pp. 52-60.

8. Avksentieva A.P., Kuris Yu.V. A study on influence of biogas composition on harmul impurites emissions. Polish journal of science, 2021, №38, pp. 34-38.

9. Avksentieva A.P., Kuris Yu.V. Research on technology and methods for utilization of biogas. SWorld Journal, 2020, №38, pp. 12-18.

10. Agricultural biotechnology: textbook / B.C. Shevelukha, E. A. Kalashnikova, E. S. Voronin et al., edited by V.S. Shevelukha - $2^{\text {nd }}$ ed., revised and enlarged - Moscow: Vyssh. Shk., 2003. - 469p. il.

11. Skorokhodov A. N. General methodology of modeling process solutions and hardware and software for their implementation according to the criteria of energy and resource saving// Bulletin of the MSAU federal state educational institution of higher professional education. No. 4, 2005, pp. 56-61.

12. Kuris Yu. V., Tkachenko S. I. Description of the calculation of heat loss of a biogas plant / / Professional magazine "Power and electrification" Kuris Yu. V., Stepanov D. V., Tkachenko S. I., Khazhmuradov M. A., Karnatsevich L. V. Increasing the efficiency of further use and burning of biogas: "Achievements and prospects». // Professional magazine "Power and electrification". Kiev, No. 12, 2006, pp. 67-79.

13. Martyniuk A.A. Technical stability in dynamics. Kiev: Technika, 1973. $188 \mathrm{p}$.

14. Kuris Yu. V., Kriuchkov E. N. Analysis of the energy balance of the production and livestock complex of Zaporizhstal CJSC with the use of a bio - energy installation // The conference proceedings "Biotechnology: Education, Science", NTU KPI. - 2003. pp. 141-143.

15. Kuris Yu. V., Kriuchkov E. N., Shinkarenko L. M. Economic and ecological areas of using biotechnological methods in the environment. // The conference proceedings "Pont Evksinsky III", - Sevastopol, - No. 1. - 2003. - pp. 27-30.

16. Kuris Yu. V. Advantages of biotechnologies in solving energy issues. // Proceedings of the anniversary XXX international scientific and technical conference "Zaporizhstal XXX". - Zaporozhie: Zaporizhstal. 2003, pp. 53-57.

17. Kuris Yu. V., Maistrenko A. Yu., Tkachenko S. I. Systematization of biogas plant schemes and optimization of energy efficiency in works of an anaerobic reactor // Professional magazine "Power and electrification". Kiev, - No. 8. - 2008. pp. 31-39.

18. Kuris Yu. V., Tkachenko S. I. Analysis of the efficiency of global energy and environmental use of biomass // Professional magazine "Power Generating Industry". 4. Kiev, - No. 5. - 2008. - pp. 35-41. 